\title{
In vitro prevention by ACE inhibitors of cataract induced by glucose
}

\author{
D. G. Langade, G. Rao*, R. C. Girme ${ }^{\star \star}$, P. S. Patki ${ }^{\star \star \star}$, P. M. Bulakh**
}

$$
\begin{array}{r}
\text { Department of Pharmacology, } \\
\text { Grant Medical College, } \\
\text { Mumbai, } \\
\text { *Ranbaxy Laboratories Ltd., } \\
\text { **Department of Biochemistry, } \\
\text { B.J. Medical College, Pune, } \\
\text { ** Department of } \\
\text { Pharmacology, B.J. Medical } \\
\text { College, Pune. }
\end{array}
$$

Received: 16.5.2005

Revised: 13.6 .2005

Accepted: 21.10 .2005

Correspondence to:

Deepak G. Langade

E-mail: drdeepakl@gmail.com

\begin{abstract}
Objectives: To study, the anticataract activity of lisinopril and enalapril on cataract induced by glucose, in goat lenses.

Materials and Methods: Goat lenses were incubated in artificial aqueous humor containing $55 \mathrm{mM}$ glucose (cataractogenesis) with lisinopril or enalapril in different concentrations at room temperature for $72 \mathrm{~h}$. Biochemical parameters studied in the lens were electrolytes $\left(\mathrm{Na}^{+}, \mathrm{K}^{+}\right), \mathrm{Na}^{+}-\mathrm{K}^{+}$-ATPase activity, malondialdehyde (MDA) and proteins.

Results: Glucose induced opacification of goat lens began 8-10 hrs after incubation and was complete in 72-80 hrs. Cataractous lenses showed higher $\mathrm{Na}^{+}, \mathrm{MDA}(\mathrm{P}<0.001)$, lower $\mathrm{Na}^{+}-\mathrm{K}^{+}$-ATPase activity, and water-soluble protein content. Lenses treated with lisinopril or enalapril in concentrations of 1,5 , and $10 \mathrm{ng} / \mathrm{ml}$ showed higher protein (total and water soluble proteins) content and prevented formation and progress of cataract by glucose, as evidenced by biochemical parameters.

Conclusion: The anticataract activity of lisinopril and enalapril may be because of the antioxidant and free radical scavenging activity, as evidenced by a decrease in MDA in treated lenses. Further in-vitro and in-vivo studies in various experimental models and long term clinical trials are required to validate the anticataract activity of ACE-inhibitors.

KEY WORDS: Antioxidant, enalapril, lisinopril.
\end{abstract}

\section{Introduction}

Cataract is the opacification of lens often associated with old age and is a major complication of diabetes mellitus because higher glycosylated hemoglobin levels are significantly associated with increased risk of cataract. ${ }^{[1]}$ Although many cataractogenic factors have been identified, the biochemical background of cataractogenesis is still unknown. The lens $\mathrm{Na}^{+}-$ $\mathrm{K}^{+}$-ATPase activity plays an important role in maintaining lens transparency, and its alteration is one of the major events leading to the cataract formation. ${ }^{|2|}$ Oxidative damage by the free radicals is also implicated in the pathology of cataractogenesis. ${ }^{[3]}$ Although a number of agents have been tried for prevention and therapy of cataract, none have proved useful. ${ }^{[4]}$ ACE inhibitors have been found to afford protection from free radical damage in many experimental conditions. ${ }^{[5]-[8]}$ Therefore, this study was conducted to find the efficacy of lisinopril and enalapril in the prevention of experimental cataract induced by glucose.

\section{Materials and Methods}

Various in vivo or in vitro experimental models in rats, mice, and rabbits have been utilised to study cataractogenesis. In this study, goat lenses were used as they were easily available. The study was approved by the institutional ethics committee.

Lens culture

Fresh goat eyeballs were obtained from slaughterhouse immediately after slaughter and transported to the laboratory at 0-4 degree Celsius. The lenses were removed by extracapsular extraction and incubated in artificial aqueous humor (NaCl $140 \mathrm{mM}$, KCl $5 \mathrm{mM}, \mathrm{MgCl}_{2} 2 \mathrm{mM}, \mathrm{NaHCO}_{3} 0.5$ $\mathrm{mM}, \mathrm{NaH}(\mathrm{PO} 4)_{2} 0.5 \mathrm{mM}, \mathrm{CaCl}_{2} 0.4 \mathrm{mM}$ and Glucose $5.5 \mathrm{mM}$ ) at room temperature and $\mathrm{pH} 7.8$ for $72 \mathrm{~h} .{ }^{[9]}$ Penicillin $32 \mathrm{mg} \%$ and streptomycin $250 \mathrm{mg} \%$ were added to the culture media to prevent bacterial contamination. Glucose in a concentration of $55 \mathrm{mM}$ was used to induce cataract. ${ }^{[9]}$ At high concentrations, glucose in the lens was metabolised through sorbitol pathway and accumulation of polyols (sugar alcohols), causing overhydration and oxidative stress. This led to cataractogenesis.

Study drugs and groups

Lisinopril, enalapril, and captopril have been reported to possess free radical scavenging activity. Lisinopril and enalapril are used commonly in clinical practice, therefore, lisinopril and enalapril are used for this study. $\mathrm{EC}_{50} \& \mathrm{EC}_{90}$ concentrations for ACE inhibition with lisinopril are $5-20$ and $27 \mathrm{ng} / \mathrm{ml}$, 
respectively, in humans after oral administration. Data on the concentrations of lisinopril and enalapril in ocular tissues after oral administration is not available. As this is a first study using ACE inhibitors, we planned to use concentrations of lisinopril and enalapril ranging from 1 to $10 \mathrm{ng} / \mathrm{ml}$, anticipating these concentrations in ocular tissues in therapeutic doses used for cardiovascular conditions.

A total of 80 lenses were divided into following categories $(n=10$ in each category):

Group I : Normal lens [Control (Glucose 5.5mM)]

Group II : Glucose 55mM

Group III

A : Glucose $55 \mathrm{mM}+$ Lisinopril $1 \mathrm{ng} / \mathrm{ml}$

B : Glucose $55 \mathrm{mM}+$ Lisinopril $5 \mathrm{ng} / \mathrm{ml}$

Group IV

C : Glucose $55 \mathrm{mM}+$ Lisinopril $10 \mathrm{ng} / \mathrm{ml}$

A : Glucose $55 \mathrm{mM}+$ Enalapril $1 \mathrm{ng} / \mathrm{ml}$

$\mathrm{B}$ : Glucose $55 \mathrm{mM}+$ Enalapril $5 \mathrm{ng} / \mathrm{ml}$

C : Glucose $55 \mathrm{mM}+$ Enalapril $10 \mathrm{ng} / \mathrm{ml}$

Homogenate preparation

After $72 \mathrm{~h}$ of incubation, homogenate of lenses was prepared in Tris buffer $(0.23 \mathrm{M}, \mathrm{pH} 7.8)$ containing $0.25 \times 10^{-3} \mathrm{M}$ EDTA and homogenate adjusted to $10 \% \mathrm{w} / \mathrm{v}$.

The homogenate was centrifuged at $10,000 \mathrm{G}$ at $4^{\circ} \mathrm{C}$ for 1 hour and the supernatant used for estimation of biochemical parameters. For estimation of water-soluble proteins, homogenate was prepared in sodium phosphate buffer $(\mathrm{pH}$ 7.4).

Biochemical estimation

Electrolyte $\left(\mathrm{Na}^{+} \& \mathrm{~K}^{+}\right)$estimation was done by flame photometry. $\mathrm{Na}^{+}-\mathrm{K}^{+}$-ATPase activity was assessed by the method of Unakar \& Tsui ${ }^{[10]}$ and protein by Lowry's method. ${ }^{[11]}$ The degree of oxidative stress was assessed by measuring the MDA levels by Wilbur's method. ${ }^{[12]}$

\section{Photographic evaluation}

Lenses were placed on a wired mesh with posterior surface touching the mesh, and the pattern of mesh (number of hexagons clearly visible through the lens) was observed through the lens as a measure of lens opacity.

\section{Statistical analysis}

All data were expressed as mean \pm SD. The groups were compared using one-way ANOVA with post-hoc Dunnett's test using glucose $55 \mathrm{mM}$ group as control. $\mathrm{P}<0.05$ was considered significant.

\section{Results}

Incubation of lenses with glucose $55 \mathrm{mM}$ showed opacification starting after $8 \mathrm{hrs}$ at the periphery, on the posterior surface of the lens. This progressively increased towards the centre, with complete opacification at the end of $72 \mathrm{hrs}$.

\section{Biochemical changes}

Glucose $55 \mathrm{mM}$ treated lenses showed significantly higher $\mathrm{Na}^{+}(\mathrm{P}<0.05)$, lower $\mathrm{K}^{+}(\mathrm{P}<0.001)$ and lower $\mathrm{Na}^{+}-\mathrm{K}^{+}$-ATPase activity $(\mathrm{P}<0.001)$ compared with normal lenses. [Table 1] Both lisinopril and enalapril treated lenses, in concentrations of 1,5 , and $10 \mathrm{ng} / \mathrm{ml}$ showed significantly high $\mathrm{K}^{+}(\mathrm{P}<0.001)$, while $\mathrm{Na}^{+}-\mathrm{K}^{+}$-ATPase activity was significantly higher $(\mathrm{P}<0.001)$ with concentrations of 5 and $10 \mathrm{ng} / \mathrm{ml}$, compared with glucose $55 \mathrm{mM}$ alone group. [Table 1] Both ACE inhibitors treated groups showed a lower $\mathrm{Na}^{+}$compared with glucose $55 \mathrm{mM}$ group at all three concentrations, but the difference was not statistically significant $(\mathrm{P}>0.05)$.

Glucose $55 \mathrm{mM}$ treated lenses also showed significantly low concentrations of proteins (total and water soluble proteins) in the lens homogenate $(\mathrm{P}<0.001)$ and very high MDA $(\mathrm{P}<0.001)$ compared with control group having normal lenses. [Table 2] Both lisinopril and enalapril groups had significantly higher concentrations of total lens proteins at 5 and $10 \mathrm{ng} / \mathrm{ml}$ concentrations $(\mathrm{P}<0.05)$, compared with glucose $55 \mathrm{mM}$ group. At the same time, they had higher water-soluble proteins at all three concentrations of lisinopril and enalapril, compared with glucose $55 \mathrm{mM}$ group. However, the difference was not significant statistically. [Table 2]

MDA levels were found to be very high in glucose $55 \mathrm{mM}$ treated lenses, compared with normal lenses (60.7 Vs 2.9). Lenses treated with lisinopril and enalapril had significantly reduced MDA content $(\mathrm{P}<0.01)$ at all the three concentrations, compared with glucose group. [Table 2]

\section{Table 1}

$\mathrm{Na}^{+}, \mathrm{K}^{+}$and $\mathrm{Na}^{+}-\mathrm{K}^{+}$-ATPase activity in lens homogenate after $72 \mathrm{~h}$ of incubation

\begin{tabular}{|c|c|c|c|c|}
\hline \multicolumn{2}{|c|}{ Study Groups } & $\mathrm{Na}^{+}[\mathrm{meq} / \mathrm{gm}]$ & $K^{+}[m e q / g m]$ & $\mathrm{Na}^{+}-\mathrm{K}^{+}-\mathrm{ATPase}$ activity $[\mu \mathrm{gP} / \mathrm{gm}]$ \\
\hline \multicolumn{2}{|c|}{ Normal [Control] } & $153.7 \pm 57.1^{*}$ & $10.5 \pm 1.5^{\star * *}$ & $41.8 \pm 2.2^{* * *}$ \\
\hline \multicolumn{2}{|c|}{ Glucose 55 mM } & $209.7 \pm 29.7$ & $6.4 \pm 0.3$ & $17.7 \pm 4.9$ \\
\hline \multicolumn{2}{|c|}{ Glucose $55 \mathrm{mM}+$ Lisinopril $5 \mathrm{ng} / \mathrm{ml}$} & $187.5 \pm 29.4$ & $9.2 \pm 1.8^{*}$ & $35.5 \pm 7.0^{* * *}$ \\
\hline \multicolumn{2}{|c|}{ Glucose $55 \mathrm{mM}+$ Lisinopril $10 \mathrm{ng} / \mathrm{ml}$} & $180.0 \pm 40.4$ & $10.6 \pm 2.4^{* * *}$ & $35.4 \pm 9.5^{\star * *}$ \\
\hline \multicolumn{2}{|c|}{ Glucose 55 mM + Enalapril 1 ng/ml } & $177.5 \pm 38.0$ & $9.5 \pm 2.5^{\star *}$ & $24.7 \pm 10.7$ \\
\hline \multicolumn{2}{|c|}{ Glucose 55 mM + Enalapril 10 ng/ml } & $180.0 \pm 43.7$ & $9.2 \pm 2.0^{*}$ & $32.9 \pm 10.5^{* * *}$ \\
\hline \multirow{3}{*}{$\begin{array}{l}\text { One-way } \\
\text { ANOVA }\end{array}$} & $\mathrm{F}$ & 1.516 & 3.970 & 10.619 \\
\hline & df & 7,72 & 7,72 & 7,72 \\
\hline & $\mathrm{P}$ & 0.176 & 0.001 & $<0.0001$ \\
\hline
\end{tabular}

Values are mean \pm SD. $n=10$ for each group. ${ }^{*} \mathrm{P}<0.05,{ }^{* *} \mathrm{P}<0.01$ and ${ }^{* * *} \mathrm{P}<0.001$ as compared with their corresponding value in glucose $55 \mathrm{mM}$ group. 
Table 2

Proteins (total proteins and water soluble proteins) and malondialdehyde (MDA) in lens homogenate after $72 \mathrm{~h}$ of incubation

\begin{tabular}{lccc}
\hline Study Groups & Total proteins [mg/gm] & Water soluble proteins [mg/gm] & MDA [nmole/gm] \\
\hline Normal [Control] & $226.8 \pm 33.9^{* * *}$ & $94.1 \pm 18.4^{* *}$ & $2.9 \pm 1.1^{* * *}$ \\
Glucose $55 \mathrm{mM}$ & $160.8 \pm 29.1$ & $61.6 \pm 29.4$ & $60.7 \pm 20.0$ \\
Glucose $55 \mathrm{mM}$ + Lisinoril $1 \mathrm{ng} / \mathrm{ml}$ & $165.8 \pm 32.0$ & $69.0 \pm 23.8$ & $42.8 \pm 12.2^{* *}$ \\
Glucose $55 \mathrm{mM}$ + Lisinoril $5 \mathrm{ng} / \mathrm{ml}$ & $205.8 \pm 29.0^{* *}$ & $72.3 \pm 21.7$ & $32.5 \pm 8.7^{* * *}$ \\
Glucose $55 \mathrm{mM}+$ Lisinoril $10 \mathrm{ng} / \mathrm{ml}$ & $202.4 \pm 17.1^{*}$ & $70.7 \pm 25.4$ & $24.3 \pm 13.1^{* * *}$ \\
Glucose $55 \mathrm{mM}+$ Enalapril $1 \mathrm{ng} / \mathrm{ml}$ & $187.4 \pm 45.6$ & $65.7 \pm 28.0$ & $37.37 \pm 14.3^{* * *}$ \\
Glucose $55 \mathrm{mM}+$ Enalapril $5 \mathrm{ng} / \mathrm{ml}$ & $214.9 \pm 27.7^{* * *}$ & $65.7 \pm 25.8$ & $27.4 \pm 7.4^{* * *}$ \\
Glucose $55 \mathrm{mM}+$ Enalapril $10 \mathrm{ng} / \mathrm{ml}$ & $210.8 \pm 23.5^{* *}$ & $69.9 \pm 29.3$ & $27.9 \pm 9.3^{* * *}$ \\
\hline One-way $\quad \mathrm{F}$ & 6.265 & 2.151 & 22.041 \\
ANOVA $\quad \mathrm{df}$ & 7,72 & 7,72 & 7,72 \\
& $<$ & 0.0001 & $<0.0001$
\end{tabular}

Values are mean $\pm S D . n=10$ for each group. ${ }^{*} P<0.05,{ }^{* *} P<0.01$ and ${ }^{* * *} \mathrm{P}<0.001$ as compared with their corresponding value in glucose $55 \mathrm{mM}$ group.

\section{Photographic evaluation [Figure-1]}

After $72 \mathrm{~h}$ of incubation in glucose $55 \mathrm{mM}$, lens becomes completely opaque ('C') as against lenses incubated in $5.5 \mathrm{mM}$ glucose ('A'). Incubation of lenses with lisinopril and enalapril, at all concentrations, seem to retard the progression of lens opacification, compared with control group (glucose $55 \mathrm{mM}$ ). This is because more number of hexagons are clearly visible in 'B' (Glucose $55 \mathrm{mM}+$ Lisinopril $10 \mathrm{ng} / \mathrm{ml}$ ) than in 'C' (Glucose $55 \mathrm{mM}$ ).

Figure 1. (A) Normal lens after $72 \mathrm{~h}$ of incubation (Transparency maintained, more hexagons clearly visible). (B) After 72 hours of incubation in glucose $55 \mathrm{mM}+$ lisinopril $10 \mathrm{ng} / \mathrm{ml}$, lens appears slightly hazy (less no. of hexagons clearly visible). (C) Complete cataractogenesis after $72 \mathrm{~h}$ of incubation in glucose $55 \mathrm{mM}$ (Complete loss of transparency, no hexagons visible through lens).

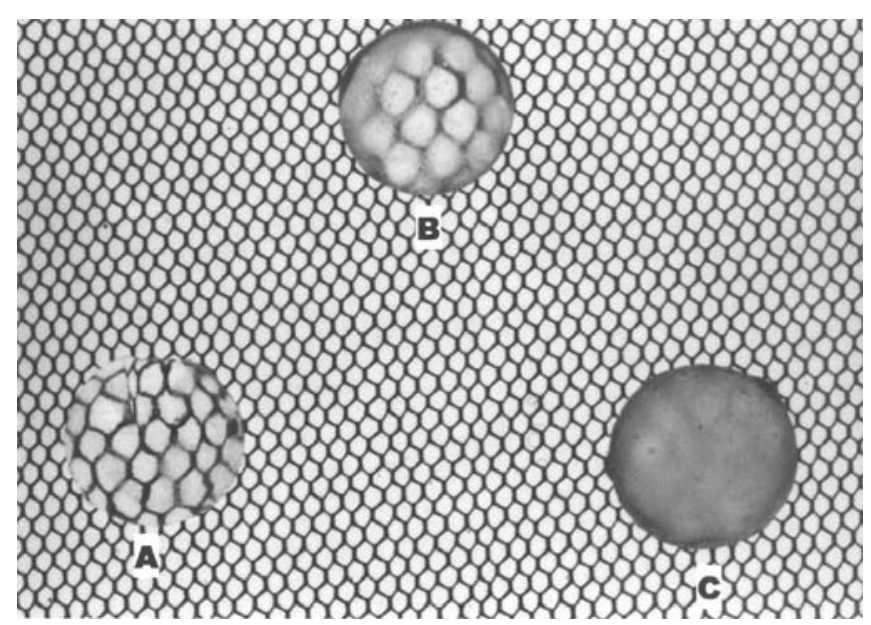

\section{Discussion}

In cataractogenesis, the parameters commonly considered are electrolytes $\left(\mathrm{Na}^{+}\right.$and $\mathrm{K}^{+}$), malondialdehyde (MDA) and proteins (total proteins and water soluble proteins).

Incubation in the media containing high glucose (55 mM) concentration has shown to cause considerable drop in $\mathrm{Na}^{+}-$ $\mathrm{K}^{+}$-ATPase activity, with progression of opacity. ${ }^{[10]}$ This study, is in agreement with this finding. $\mathrm{Na}^{+}-\mathrm{K}^{+}$-ATPase is important in maintaining the ionic equilibrium in the lens, and its impairment causes accumulation of $\mathrm{Na}^{+}$and loss of $\mathrm{K}^{+}$with hydration and swelling of the lens fibers leading to cataractogenesis. ${ }^{[13]}$ This alteration in the $\mathrm{Na}^{+}-\mathrm{K}^{+}$ratio alters the protein content of the lens, leading to a decrease in watersoluble proteins' content and increase in insoluble proteins. This causes lens opacification. ${ }^{144}$ This study showed higher $\mathrm{Na}^{+}-\mathrm{K}^{+}$-ATPase activity, total and water-soluble proteins and $\mathrm{K}^{+}$ions whereas lower concentrations of $\mathrm{Na}^{+}$ions with lisinopril and enalapril treated groups. Therefore, these ACE inhibitors seem to prevent the alteration of $\mathrm{Na}^{+}$and $\mathrm{K}^{+}$ imbalance, which may be due to a direct effect on lens membrane $\mathrm{Na}^{+}-\mathrm{K}^{+}-$ATPase or indirect effect through their free radical scavenging activity.

Oxidative stress may also be implicated in the cataract induced by glucose, due to the formation of superoxide $\left(\mathrm{O}_{2}{ }^{-}\right)$ radicals and $\mathrm{H}_{2} \mathrm{O}_{2}$. High glucose $(55 \mathrm{mM})$ has shown to induce antioxidant enzymes, suggesting oxidative stress in the cells. ${ }^{\mid 15]}$ In this study MDA levels were significantly higher in high glucose (55 mM) group, compared with normal control group. The MDA levels were significantly less in the lisinopril and enalapril treated groups at all concentrations. These results are in agreement with those of Bhuyan $\mathrm{KC}$, et al. ${ }^{116 l}$ They found significant reduction in the rate of superoxide $\left(\mathrm{O}_{2}{ }^{-}\right)$production in animals treated with captopril, in cataract model induced by diquat in rabbits. Noda Y, et al. ${ }^{171}$ demonstrated scavenging activity of lisinopril on nitric oxide. Lisinopril and enalapril have also been shown to increase the content of water-soluble proteins, retarding the process of cataractogenesis initiated by high glucose concentration. 
Incubation in presence of high glucose (55 mM) concentration simulates a state of clinical diabetes where ACE inhibitors are commonly used in these patients to treat associated cardiovascular disorders. A preventive role of lisinopril and enalapril as seen in this in vitro model may, to some extent, suggest an additional utility of ACE inhibitors in the form of preventing and/or retarding the progression of diabetic cataracts.

The concentrations of lisinopril and enalapril used in this study ranged between 1 to $10 \mathrm{ng} / \mathrm{ml}$. However, higher concentrations upto $20 \mathrm{ng} / \mathrm{ml}$ may show better anticataract activity, and further evaluation with higher concentrations is required. This in vitro study may not directly correlate with the in vivo conditions. Therefore, in vivo studies in different animal models are required for further elucidation of the role of ACE inhibitors in preventing cataract.

\section{Conclusion}

Lisinopril and enalapril demonstrated in vitro anticataract activity in experimental cataract induced by high glucose. Further in vitro and in vivo studies to elucidate the exact mechanism of ACE inhibitors in prevention of cataractogenesis are needed. Clinical evaluation of patients already receiving ACE inhibitors may be followed to identify the presence of the additional benefit of cataract prevention/progression.

\section{References}

1. Klein BEK, Klein R, Lee KE. Cardiovascular disease, selected cardiovascular disease risk factors and age related cataracts: The beaver dam eye study. Am J Ophthalmol 1997;123:338-46.

2. Unakar NJ, Tsui JY. Inhibition of galactose induced alteration in ocular lens with sorbinil. Exp Eye Res 1983;36:685-94.
3. Cheng HM, Fagarhoilm P, Chylack LT. Response of lens to oxidative-osmotic stress. Exp Eye Res 1983;37:11-21.

4. Gupta SK, Joshi S, Velpandian T, Awor L, Prakash J. An update on pharmacological prospectives for prevention and development of cataract. Indian J Pharmacol 1997;29:3-10.

5. Gillis $\mathrm{CN}$, Chen X, Merker MM. Lisinopril and ramiprilat protection of the vascular endothelium against free radical-induced functional injury. J Pharmacol Exp Ther 1992;262:212-6.

6. Hayek T, Attias J, Breslow JL, Keidar S. Antiatherosclerotic and antioxidative effects of captopril in apolipoprotein-E-deficient mice. J Cardiovasc Pharmacol 1998:31:540-4.

7. Ruiz-Munoz LM, Vidal-Vanaclocha F, Lampreabe I. Enalaprilat inhibits hydrogen peroxide production by murine mesangial cells exposed to high glucose concentrations. Nephrol Dial Transplant 1997;12;456-64.

8. Elena MV, de Cavanagh EM, Inserra F, Ferder L, Fraga CG. Enalapril and captopril enhance glutathione-dependent antioxidant defenses in mouse tissues. AJP-Regulatory, Integrative and Comparative Physiology 2000; 278:R572-77.

9. Chandorkar AG, Albal MV, Bulakh PM. Muley MP. Lens Organ Culture. Indian J Opthalmol 1981;29:151-2.

10. Unakar NJ, Tsui JY. Measurement of $\mathrm{Na}^{+}-\mathrm{K}^{+}-$ATPase activity. Invest Opth Vise Sci 1980;19:378-85.

11. Lowry O, Rosebrough A, Farr A, Randall R. Protein measurement with the Folin phenol reagent. J Biol Chem 1951;193:265.

12. Wilbur KM. Estimation of lipid peroxide. Arch Biochem Biophysics 1949;24: 305-15.

13. Chylack LT, Kinashita JH. A biochemical evaluation of a cataract induced in a high glucose medium. Invest Opthalmol 1969;8:401-12.

14. Shinohara T, Piatigorsky J. Regulation of protein synthesis, intracellular electrolytes and cataract formation in vitro. Nature 1977;270:406-11.

15. Ceriello A, Russo PD, Amsted P, Cerutti P. High glucose induces antioxidant enzymes in human endothelial cells in culture. Diabetes 1996;45:471-7.

16. Bhuyan KC, Bhuyan DK, Santos O, Podos SM. Antioxidant and anticataract effects of topical captopril in diquat induced cataract in rabbits. Free Rad Biol Med 1992;12:251-61.

17. Noda Y, Mori A, Packer L. Free radical scavenging properties of alacepril metabolites and lisinopril. Res Commun Mol Pathol Pharmacol 1997;96: $125-36$.

\section{INTERNATIONAL CONFERENCE ON TOXICOLOGY, TOXICOGENOMICS AND OCCUPATIONAL HEALTH (ICTTOH)}

\section{$26^{\text {th }}$ ANNUAL MEETING OF SOCIETY OF TOXICOLOGY (STOX) INDIA 9-11 OCTOBER 2006}

For further detials, please cotanct:

\author{
Dr. Sangeeta Shukla \\ Organizing Secretary, \\ School of Studies in Zoology, \\ Jiwaji University, Gwalior-474011. India \\ E-mail: rblstox26@rediffmail.com
}

